\title{
Pengaruh Suhu Terhadap Kadar Air Dan Aktivitas Air Dalam Bahan Pada Kunyit (Curcuma Longa) Dengan Alat Pengering Electrical Oven
}

\author{
Wilandika Leviana dan Vita Paramita* \\ Teknik Kimia Departemen Teknologi Industri, Sekolah Vokasi, Universitas Diponegoro \\ Jl. Prof. Soedarto, Tembalang, Kota Semarang, Jawa Tengah 50275, Indonesia \\ Email : vita.paramita@gmail.com
}

\begin{abstract}
Abstrak
Kunyit merupakan tanaman obat berupa semak dan bersifat tahunan (parenial). Kandungan air yang cukup tinggi membuat kunyit harus diolah sebelum disimpan dalam jangka waktu yang lama. Pada penelitian ini pengeringan kunyit dengan menggunakan electrical oven. Proses pengeringan kunyit dilakukan dengan variabel berubah seperti jenis bahan, suhu, dan ketebalan irisan. Jenis bahan yang digunakan yaitu kunyit orange dan kunyit putih, variabel suhu pengeringan $70^{\circ} \mathrm{C}, 80^{\circ} \mathrm{C}, 100^{\circ} \mathrm{C}$ serta variabel irisan $1 \mathrm{~mm}, 2 \mathrm{~mm}, 3 \mathrm{~mm}$, dan $4 \mathrm{~mm}$. Uji analisa pada penelitian ini meliputi analisa kadar air, aktivitas air, dan organoleptik seperti uji warna, aroma, dan penampakan fisik. Pada penilitian tersebut didapatkan variabel optimal pada jenis kunyit orange dan putih yaitu pada variabel suhu pengeringan $80^{\circ} \mathrm{C}$ dengan ketebalan irisan $3 \mathrm{~mm}$ waktu pengeringan selama 135 menit untuk kunyit putih dan 150 menit untuk kunyit orange. Kadar air sebesar 3,515\% dan 0,11 aktivitas air pada kunyit putih, aroma dan bentuk yang khas warna dan kunyit serta tidak berubah bentuk, sedangkan pada kunyit orange kadar air sebesar 2,741\% dan aktivitas air sebesar 0,061 aroma yang sedikit khas kunyit dengan warna putih kekuningan.
\end{abstract}

Kata kunci : kunyit, electrical oven, kadar air, aktivitas air

\section{Abstract \\ Effect of Temperature on Water Content And Water Activity In Material On Turmeric (Curcuma Longa) With Tools Electrical Oven Dryer}

Turmeric is a medicinal plant of bush and annual (parenial). The water content is high enough to make turmeric should be processed before being stored for long periods. In this research drying turmeric using electrical oven. The process of drying turmeric by changing variables such as material type, temperature, and slice thickness. Type of materials used are orange turmeric and white turmeric, drying temperature variables $70^{\circ} \mathrm{C}, 80^{\circ} \mathrm{C}, 100^{\circ} \mathrm{C}$ and variable slices $7 \mathrm{~mm}, 2 \mathrm{~mm}, 3 \mathrm{~mm}$, and $4 \mathrm{~mm}$. Test analysis in this study include water content, water activity, and organoleptic analysis such as color, aroma, and physical appearance. In the research, the optimum variables on turmeric and white turmeric were varied in drying temperature $80^{\circ} \mathrm{C}$ with $3 \mathrm{~mm}$ slice thickness drying time for 135 minutes for white turmeric and 150 minutes for turmeric. Water content of 3,515\% and 0.11 of water activity in white turmeric, aroma and shapes typical of color and turmeric and unchanged, while in turmeric orange moisture of $2.741 \%$ and water activity of 0.061 a slightly turmericwhite scent with white Yellowish.

Keywords: turmeric, electrical oven, water content, water activity 


\section{PENDAHULUAN}

Kunyit merupakan tanaman dari family Zingiberaceae (temu-temuan) yang tumbuh liar disekitar hutan atau kebun pada ketinggian 1.300 - $1.600 \mathrm{mdpl}$, tumbuh bercabang dengan tinggi $40-100 \mathrm{~cm}$ (Winarto, 2004). Kunyit kaya akan kandungan senyawa kurkuminoid yang mempunyai kemampuan sebagai anti mikroba, anti oksidan, anti jamur dan anti inflamasi Ferreira et al. (2013). Antioksidan dapat menghambat kerusakan oksidatif produk pangan dan bermanfaat bagi kesehatan (Septiana et al, 2004). Kurkumin (1,7-bis(4-hidroksi-3-metoksifenil)1E,6 Eheptadiene-3,5-dione atau diferuloyl metan), digunakan sebagai obat pada penyakit diabetes dan gagal ginjal (Trujillo et al., 2013), kanker, sakit perut (Kössler et al., 2012), epilepsi, stress, tifus, anemia, penyakit kulit, luka luar, gangguan pencernakan, panas dalam, keputihan dan gangguan kognisi (Rukmana, 1994).

Penyiapan kunyit sebagai produk yang terstandar harus memperhatikan pengolahannya secara benar, karena mutu dan khasiat produk dapat berkurang atau kemungkinan dapat menimbulkan toksik. Toksik yang dihasilkan biasanya berasal mikroorganisme karena kadar air dan aktivitas air dalam kunyit yang tinggi, sehingga menyebabkan penurunan kualitas kunyit (Kusumaningrum, 2015). Kapang, khamis, bakteri, dan jamur dapat tumbuh pada bahan yang nilai aktivitas airnya tinggi. Misalnya bakteri Aw : 0,90; khamir Aw : 0,80-0,90; kapang Aw : 0,60-0,70 (Belitz, 2009). Cara menurunkan nilai Aw antara lain dengan menambahkan suatu senyawa yang dapat mengikat air, umumnya dilakukan pengeringan, baik dengan penjemuran atau dengan alat pengering buatan. Metode pengeringan merupakan proses penghilangan kandungan air dalam suatu zat padat (solid) atau campuran gas dengan menggunakan sumber panas (McCabe et al., 1993). Proses pengeringan dipengaruhi oleh udara pengering dan ketebalan bahan yang dikeringkan. Semakin tipis bahan maka semakin cepat waktu pengeringannya (Rahmawan, 2001).

Penelitian tentang pengeringan kunyit telah dilakukan oleh beberapa peneliti (Saputra dan Dewi, 2010). Namun demikian, penelitian tersebut dilakukan hanya untuk analisa kadar air terhadap pengaruh suhu dan waktu saja. Pada penelitian ini akan membahas pengaruh waktu dan suhu pengeringan terhadap kadar air dan kualitas air serta pengaruhnya terhadap daya simpan makanan.

\section{METODOLOGI}

Penelitian tentang pengaruh suhu pengeringan terhadap kadar air dan aktivitas air dalam bahan pada kunyit orange dan putih dilakukan secara bertahap meliputi: tahap perlakuan awal, tahap pengeringan, dan tahap analisa.

\section{Tahap perlakuan awal}

Pada tahap perlakuan awal meliputi persiapan bahan baku, pencucian, dan pemotongan sampel sesuai variabel. Bahan baku yang digunakan dalam penelitian ini adalah kunyit orange dan kunyit putih. Alat utama yang digunakan adalah oven merk memmert tipe UN 110 (Memmert GmbH + Co. KG, Deutschland), timbangan digital ohaus, serta variabel ketebalan yang diterapkan yaitu $1 \mathrm{~mm}, 2 \mathrm{~mm}, 3 \mathrm{~mm}, 4 \mathrm{~mm}$.

\section{Tahap Pengeringan}

Kunyit orange dan putih yang telah dipotong sesuai variabel dengan ketebalan irisan $1 \mathrm{~mm}, 2 \mathrm{~mm}, 3 \mathrm{~mm}$, dan $4 \mathrm{~mm}$ kemudian akan dikeringkan dengan electrical oven merk memmert tipe UN 110 pada variabel suhu $70^{\circ} \mathrm{C}, 80^{\circ} \mathrm{C}$, dan $100^{\circ} \mathrm{C}$ dengan lama pengeringan 15 menit yang selanjutnya dilakukan penimbangan sampai didapatkan massa yang konstan.

\section{Tahap Analisa}

Tahap analisa produk yang dilakukan meliputi analisa kadar air, analisa aktivitas air, serta analisa organoleptik. Analisa kadar air bertujuan untuk mengetahui kadar air dalam bahan setelah dilakukan pengeringan sampai didapatkan massa konstan. Kadar air bahan dapat dihitung dengan persamaan sebagai berikut :

$M=\frac{W m}{W m+W d} \times 100 \%$ 
Dimana : $M=$ kadar air basis basah (\%bb), $W m=$ berat air dalam bahan (g), $W d=$ berat padatan dalam bahan atau berat bahan kering (Rahmawan, 2001). Aktivitas air adalah $\left(a_{w}\right)$ adalah perbandingan antara tekanan uap larutan dengan tekanan uap air solven murni pada temperatur yang sama. Aktivitas air dalam bahan dirumuskan dengan persamaan berikut:

$A w=\frac{P}{P 0}=\frac{E R H}{100}$

Dimana : $\mathrm{a}_{\mathrm{w}}=$ aktivitas air, $\mathrm{P}=$ kelembaban tekanan uap parsial dalam bahan, $\mathrm{P}_{0}=$ tekanan jenuh uap murni, ERH = ekuilibrium kelembaban relative (Belitz, 2009).

Analisa yang ketiga yaitu analisa organoleptik merupakan analisa dengan penilaian indera, yang meliputi aroma, warna, dan penampakan fisik. Penilaian organoleptik terdiri dari enam tahapan yaitu menerima produk, mengenali produk, mengadakan klarifikasi sifatsifat produk, mengingat kembali produk yang telah diamati, dan menguraikan kembali sifat inderawi produk. Uji organoleptik memiliki relevansi yang tinggi dengan mutu produk karena berhubungan langsung dengan selera konsumen (Fitriyono, 2014).

\section{HASIL DAN PEMBAHASAN}

\section{Kadar Air pada Kunyit Orange}

Gambar 1 menunjukkan hasil pengamatan kadar air sampel kunyit orange dengan variabel ketebalan irisan $1 \mathrm{~mm}, 2 \mathrm{~mm}, 3 \mathrm{~mm}$, dan $4 \mathrm{~mm}$ dengan electrical oven serta variabel suhu yang berbeda-beda yaitu $70^{\circ} \mathrm{C}, 80^{\circ} \mathrm{C}$, dan $100^{\circ} \mathrm{C}$. Dari ketiga variabel suhu yang digunakan menunjukkan bahwa ketebalan irisan mempengaruhi waktu pengeringan dan kadar air. Waktu pengeringan pada irisan $1 \mathrm{~mm}$ lebih cepat dibanding dengan ketebalan irisan yang lainnya $(2 \mathrm{~mm}, 3 \mathrm{~mm}, 4 \mathrm{~mm})$. Lama proses pengeringan (mencapai keadaan konstan) tergantung pada luas penampang pada bahan yang dikeringkan (Rahmawan, 2001).

Kadar air rata-rata dan waktu pengeringan yang didapat pada penelitian kadar air variabel suhu $70^{\circ} \mathrm{C}$ yaitu $30,631 \%$ dengan waktu 145 menit, pada suhu $80{ }^{\circ} \mathrm{C}$ sebesar $32.386 \%$ selama 135 menit, dan pada suhu $100^{\circ} \mathrm{C}$ sebesar $29,534 \%$ selama 90 menit. Pada setiap suhu tidak terjadi perbedaan kadar air yang begitu jauh yaitu kisaran 29-32\% begitupun dengan kadar air pada setiap ketebalan irisan. Perbedaan terdapat pada lamanya waktu pengeringan. Pada suhu $100^{\circ} \mathrm{C}$ (gambar 1c) membutuhkan waktu pengeringan yang paling cepat yaitu 90 menit dan suhu $70^{\circ} \mathrm{C}$ (gambar 1a) membutuhkan waktu pengeringan paling lama yaitu 165 menit.

Untuk uji organoleptik yang meliputi uji bau, warna, dan penampakan fisik yaitu pada pengeringan suhu $70^{\circ} \mathrm{C}$ didapatkan warna orange pucat dengan bau khas kunyit serta bentuk yang sangat keriput, suhu $80^{\circ} \mathrm{C}$ warna orange terang dengan bau khas kunyit dan tidak terjadi perubahan bentuk, dan suhu $100^{\circ} \mathrm{C}$ warna orange kecoklatan, bau khas kunyit, dan bentuk yang keriput.

Berdasarkan penelitian oleh Saputra dan Dewi (2010) melakukan penelitian yaitu dengan bahan kunyit biasa (orange) dengan ketebalan irisan dimensi $1 \times 1 \times 0,6 \mathrm{~cm}$ pada suhu $70^{\circ} \mathrm{C}$ selama 75 menit dengan pengering vacuum oven kadar air yang didapat sebesar $16,48 \%$, suhu $80{ }^{\circ} \mathrm{C}$ kadar air sebesar $5,08 \%$, dan suhu $120{ }^{\circ} \mathrm{C}$ kadar air sebesar $7,7 \%$. Sedangkan untuk uji organoleptik yaitu uji warna dan bentuk fisik (Tabel 1). Pada suhu $70^{\circ} \mathrm{C}$ warna simplisia kuning, suhu $80^{\circ} \mathrm{C}$ warna simplisia kuning, dan suhu $120^{\circ} \mathrm{C}$ warna simplisia kuningtua. Jika dibandingkan dengan penelitian dengan waktu pengeringan setiap 15 menit dengan pada suhu yang sama terdapat perbedaan kadar air dan lama waktu pengeringan yang signifikan. Hal tersebut terjadi karena alat yang digunakan pada kedua penelitian berbeda sehingga memiliki efesiensi yang berbeda pula.

\section{Aktivitas Air pada Pengeringan Kunyit Orange}

Aktivitas air $\left(a_{w}\right)$ menggambarkan derajat aktivitas air dalam bahan pangan, baik kimia dan biologis. aktivitas air sangat erat kaitannya dengan kadar air dalam bahan terhadap daya simpan (Belitz, 2009). Tinggi rendahnya nilai aktivitas air akan mempengaruhi waktu simpan dan kualitas dari bahan makanan. Range nilai aktivitas air yaitu 0 - 1. Semakin besar nilai aktivitas air maka 
semakin kecil daya tahan bahan makanan begitu pula sebaliknya semakin kecil nilai aktivitas air maka semakin lama daya simpan bahan makanan tersebut. Kandungan air dalam bahan makanan mempengaruhi daya tahan bahan makanan terhadap serangan mikroba yang dapat digunakan oleh mikroorganisme untuk pertumbuhannya. Mikroorganisme mempunyai Aw minimum agar dapat tumbuh dengan baik, seperti bakteri pada Aw 0,90; khamir Aw 0,8 - 0,9 ; kapang Aw 0,6 - 0,7. Untuk memperpanjang daya tahan suatu bahan sebagian air dalam bahan harus dihilangkan dengan beberapa cara seperti pengeringan (Belitz, 2009).

Pada pengeringan simplisia kunyit orange dilakukan analisa aktivitas air didapatkan range nilai aktivitas air terhadap pemanasan dan lamanya pengeringan yang berbeda-beda yaitu 0,3 - 0,07 pada suhu $70^{\circ} \mathrm{C}, 0,2-0,045$ pada suhu $80^{\circ} \mathrm{C}$, dan $0,2-0,04$ pada suhu $100^{\circ} \mathrm{C}$.
Berdasarkan data penelitian diatas (Gambar 2) semakin tinggi suhu dan lama waktu pemanasan akan semakin kecil pula nilai aktivitas airnya. Dalam penelitian tentang modifikasi dan pengujian alat pengasap ikan sistem kabinet, oleh Bimantara (2015), menyebutkan bahwa aktivitas air yang rendah disebabkan oleh suhu pemanasan yang tinggi.

\section{Kadar Air pada Pengeringan Kunyit Putih}

Gambar 3 menunjukkan hasil pengamatan kadar air sampel kunyit putih dengan variable ketebalan irisan $1 \mathrm{~mm}, 2 \mathrm{~mm}, 3 \mathrm{~mm}$, dan $4 \mathrm{~mm}$ menggunakan electrical oven serta varibel suhu yang berbeda-beda yaitu $70^{\circ} \mathrm{C}, 80^{\circ} \mathrm{C}$, dan $100^{\circ} \mathrm{C}$. Dari ketiga variabel suhu yang digunakan menunjukkan bahwa ketebalan irisan mempengaruhi waktu pengeringan dan kadar air. Waktu pengeringan pada irisan $1 \mathrm{~mm}$ lebih cepat

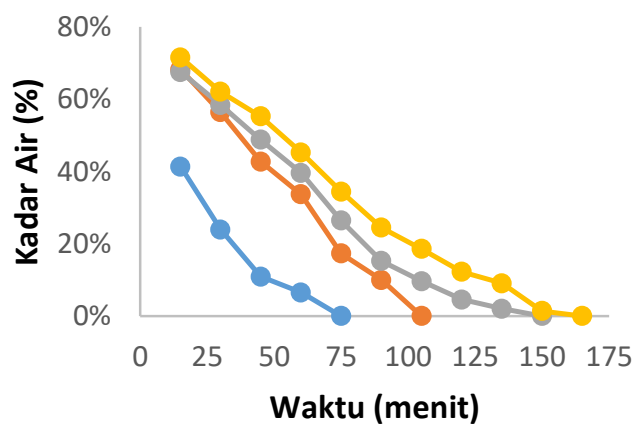

(a)

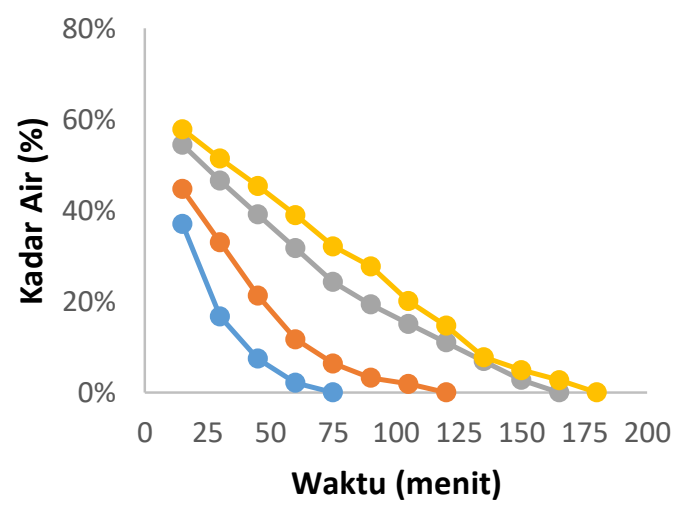

(b)

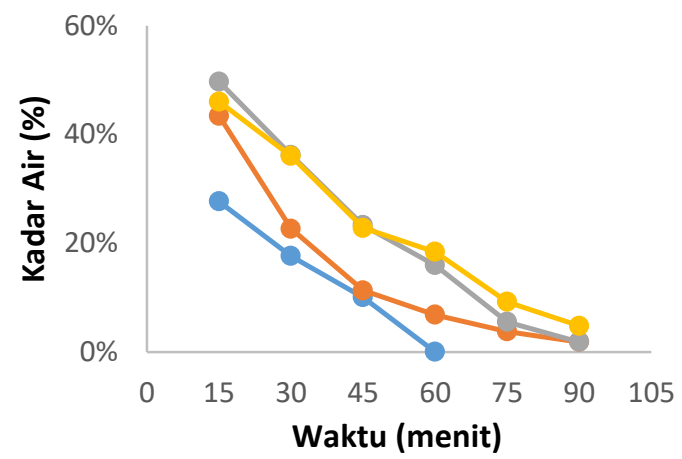

(c)

Gambar 1. Kadar Air pada Pengeringan Kunyit Orange (a) suhu $70^{\circ} \mathrm{C}$, (b) suhu $80^{\circ} \mathrm{C}$, (c) suhu $100^{\circ} \mathrm{C}$. Keterangan $: \rightarrow-, 1 \mathrm{~mm}, \rightarrow-, 2 \mathrm{~mm}, \rightarrow-, 3 \mathrm{~mm}, \rightarrow-, 4 \mathrm{~mm}$ 
Tabel 1. Uji Organoleptik Kunyit Orange

\begin{tabular}{ccccc}
\hline $\begin{array}{c}\text { Suhu } \\
\left({ }^{\circ} \mathrm{C}\right)\end{array}$ & \multicolumn{4}{c}{ Irisan $(\mathrm{mm})$} \\
\cline { 2 - 5 } 2 & 2 & 3 & 4 \\
\hline 70 & $1 \mathrm{~A}$ & $1 \mathrm{~A}$ & $1 \mathrm{~A}$ & $1 \mathrm{~B}$ \\
80 & $2 \mathrm{~B}$ & $2 \mathrm{~B}$ & $3 \mathrm{C}$ & $3 \mathrm{C}$ \\
100 & $3 \mathrm{~B}$ & $3 \mathrm{~B}$ & $3 \mathrm{~B}$ & $3 \mathrm{~B}$ \\
\hline
\end{tabular}

Keterangan :

Bentuk fisik: $A=$ sangat keriput

$B=$ sedikit keriput

$\mathrm{C}=$ tidak keriput

Warna : $\quad 1=$ Orange pucat

2 = Orange cerah

3 = Orange kecoklatan

dibanding dengan ketebalan irisan yang lainnya (2mm, 3mm, 4mm). Lama proses pengeringan (mencapai keadaan konstan) tergantung pada luas penampang pada bahan yang dikeringkan (Rahmawan, 2001). Kadar air rata-rata dan waktu pengeringan yang didapat pada penelitian kadar air variabel suhu $70^{\circ} \mathrm{C}$ yaitu $22,31 \%$ dengan waktu 135 menit, pada suhu $80{ }^{\circ} \mathrm{C}$ sebesar $19,46 \%$ selama 120 menit, dan pada suhu $100{ }^{\circ} \mathrm{C}$ sebesar 18,49\% selama 75 menit. Pada setiap suhu tidak terjadi perbedaan kadar air yang begitu jauh yaitu kisaran 17-23\% begitupun dengan kadar air pada setiap ketebalan irisan. Perbedaan terdapat pada lamanya waktu pengeringan. Pada suhu $100^{\circ} \mathrm{C}$ (gambar 3c) membutuhkan waktu pengeringan yang paling cepat yaitu 75 menit dan suhu $70^{\circ} \mathrm{C}$ (gambar 3a) membutuhkan waktu pengeringan paling lama yaitu 135 menit. Untuk uji organoleptik yang meliputi uji bau, warna, dan penampakan fisik yaitu pada pengeringan suhu $70^{\circ} \mathrm{C}$ didapatkan warna putih kekuningan dengan sedikit bau kunyit serta bentuk sangat keriput, suhu $80^{\circ} \mathrm{C}$ warna putih kekuningan dengan sedikit bau kunyit dan bentuk sangat keriput, dan suhu $100^{\circ} \mathrm{C}$ warna putih gosong, sangat sedikit bau kunyit, dan bentuk yang sangat keriput (Tabel 2).

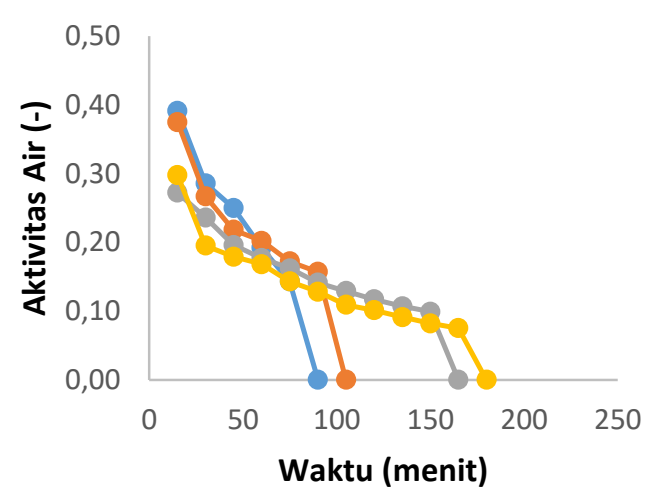

(a)

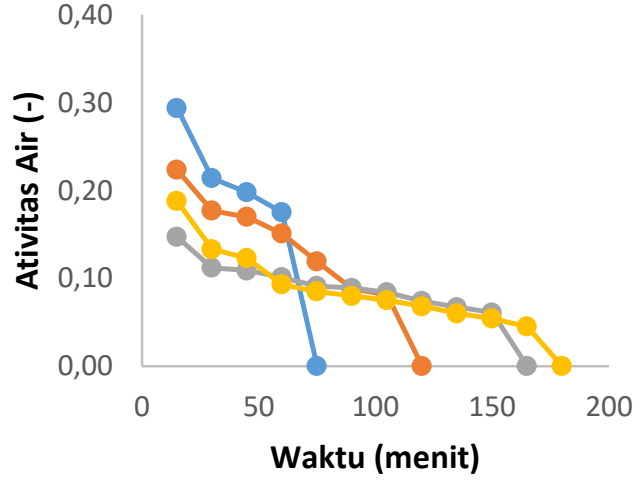

(b)

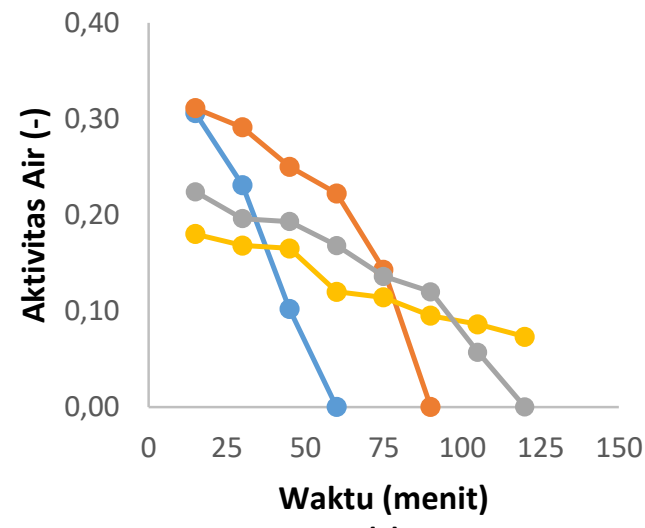

(c)

Gambar 2. Aktivitas Air pada Pengeringan Kunyit Orange (a) suhu $70^{\circ} \mathrm{C}$, (b) suhu $80^{\circ} \mathrm{C}$, (c) suhu $100^{\circ} \mathrm{C}$. Keterangan $: \rightarrow-, 1 \mathrm{~mm}, \rightarrow-, 2 \mathrm{~mm}, \rightarrow-, 3 \mathrm{~mm},-\rightarrow, 4 \mathrm{~mm}$ 


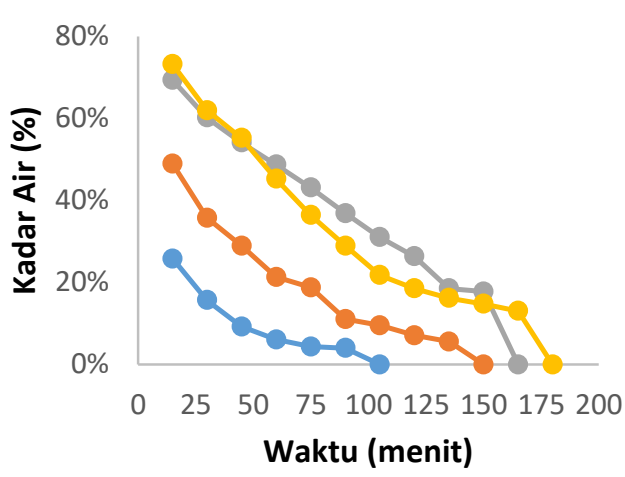

(a)

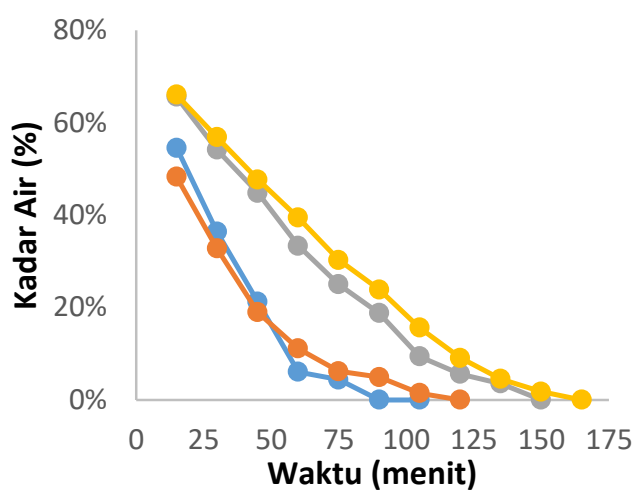

(b)

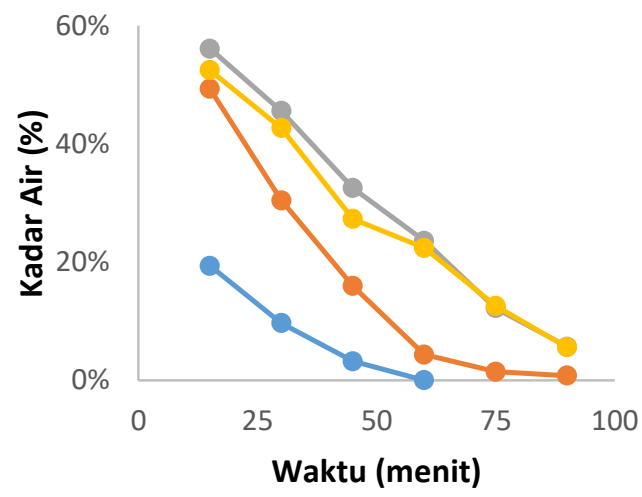

(c)

Gambar 3. Kadar Air pada Pengeringan Kunyit Putih (a) suhu $70{ }^{\circ} \mathrm{C}$, (b) suhu $80{ }^{\circ} \mathrm{C}$, (c) suhu $100{ }^{\circ} \mathrm{C}$. Keterangan : $\rightarrow-, 1 \mathrm{~mm}, \rightarrow-, 2 \mathrm{~mm}, \rightarrow-, 3 \mathrm{~mm}, \rightarrow-, 4 \mathrm{~mm}$

Tabel 2. Uji Organoleptik Kunyit Putih

\begin{tabular}{ccccc}
\hline $\begin{array}{c}\text { Suhu } \\
\left({ }^{\circ} \mathrm{C}\right)\end{array}$ & \multicolumn{4}{c}{ Irisan $(\mathrm{mm})$} \\
\cline { 2 - 5 } & 1 & 2 & 3 & 4 \\
\hline 70 & $2 \mathrm{~A}$ & $2 \mathrm{~A}$ & $2 \mathrm{~A}$ & $2 \mathrm{~A}$ \\
80 & $2 \mathrm{~A}$ & $2 \mathrm{~A}$ & $2 \mathrm{~A}$ & $2 \mathrm{~A}$ \\
100 & $3 \mathrm{~A}$ & $3 \mathrm{~A}$ & $3 \mathrm{~A}$ & $3 \mathrm{~A}$
\end{tabular}

Keterangan :

Bentuk fisik: $A=$ sangat keriput

$\mathrm{B}=$ sedikit keriput

$\mathrm{C}=$ tidak keriput

Warna : $\quad 1=$ Putih

$2=$ Putih Kekuningan

$3=$ Putih gosong

Pada penelitian oleh Saputra dan Dewi (2010) dengan bahan kunyit putih dengan ketebalan irisan dimensi $1 \times 1 \times 0,6 \mathrm{~cm}$ pada suhu $70^{\circ} \mathrm{C}$ selama 75 menit dengan pengering vacuum oven kadar air yang didapat sebesar $4,42 \%$, suhu $80{ }^{\circ} \mathrm{C}$ kadar air sebesar $5,21 \%$, dan suhu $120^{\circ} \mathrm{C}$ kadar air sebesar 6,86\%. Sedangkan untuk uji organoleptik yaitu uji warna. Pada suhu $70^{\circ} \mathrm{C}$ warna simplisia kuning keoranyenan, suhu $80^{\circ} \mathrm{C}$ warna simplisia oranye, dan suhu $120^{\circ} \mathrm{C}$ warna simplisia oranye kecoklatan. Jika dibandingkan dengan penelitian dengan waktu pengeringan setiap 15 menit dengan pada suhu yang sama terdapat perbedaan kadar air dan lama waktu pengeringan yang signifikan. Hal tersebut terjadi karena alat yang digunakan pada kedua penelitian berbeda sehingga memiliki efesiensi yang berbeda pula.

\section{Aktivitas Air pada Pengeringan Kunyit Putih}

Pada penelitian pengeringan simplisia kunyit, dilakukan analisa aktivitas air (gambar 4). Aktivitas air $\left(a_{w}\right)$ menggambarkan derajat aktivitas air dalam bahan pangan, baik kimia dan biologis. aktivitas air sangat erat kaitannya dengan kadar air dalam bahan terhadap daya simpan (Belitz, 


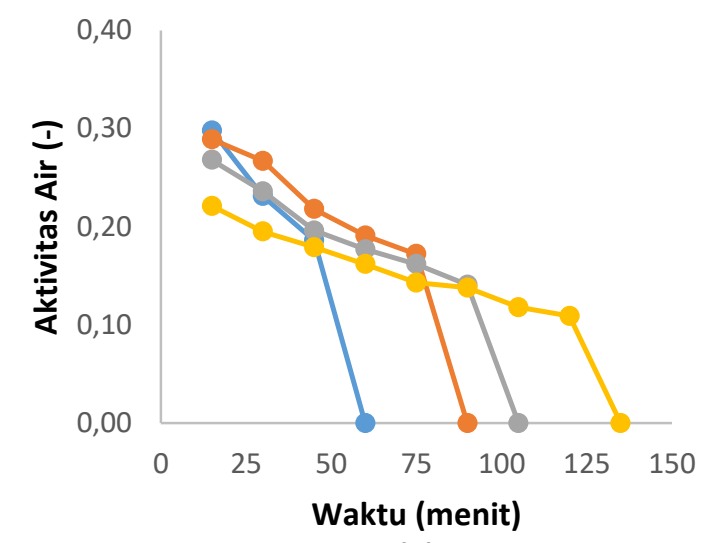

(a)

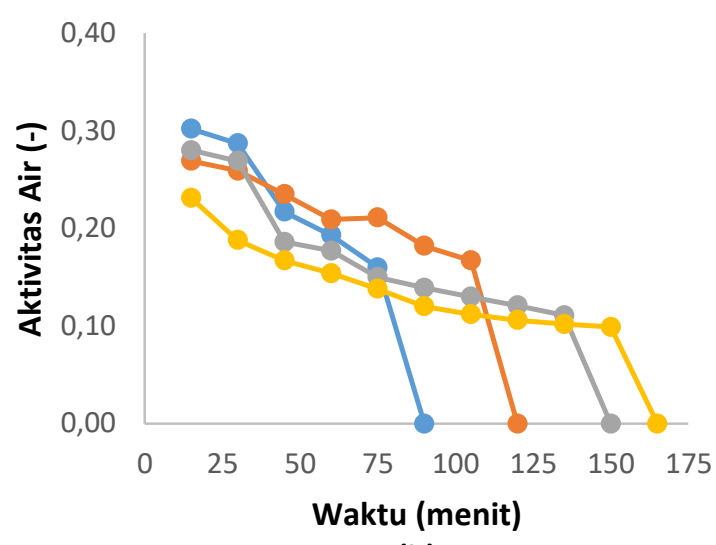

(b)

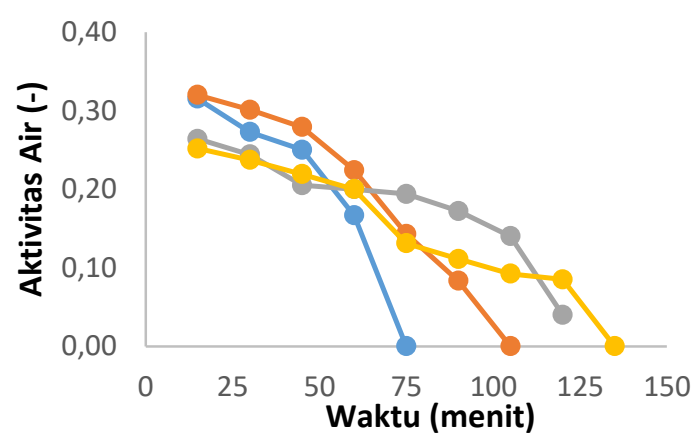

(c)

Gambar 4. Aktivitas Air pada Pengeringan Kunyit Putih (a) suhu $70{ }^{\circ} \mathrm{C}$, (b) suhu $80{ }^{\circ} \mathrm{C}$, (c) suhu $100{ }^{\circ} \mathrm{C}$. Keterangan $: \rightarrow, 1 \mathrm{~mm}, \rightarrow-, 2 \mathrm{~mm}, \rightarrow-, 3 \mathrm{~mm}, \rightarrow-, 4 \mathrm{~mm}$

2009). Range nilai aktivitas air yaitu 0 - 1. Semakin besar nilai aktivitas air maka semakin kecil daya tahan bahan makanan begitu pula sebaliknya semakin kecil nilai aktivitas air maka semakin lama daya simpan bahan makanan tersebut. Kandungan air dalam bahan makanan mempengaruhi daya tahan bahan makanan terhadap serangan mikroba yang dapat digunakan oleh mikroorganisme untuk pertumbuhannya. Mikroorganisme mempunyai Aw minimum agar dapat tumbuh dengan baik, seperti bakteri pada Aw 0,90; khamir Aw 0,8 - 0,9 ; kapang Aw 0,6 - 0,7. Untuk memperpanjang daya tahan suatu bahan, sebagian air dalam bahan harus dihilangkan dengan beberapa cara seperti pengeringan (Belitz, 2009). Pada praktikum pengeringan kunyit putih didapatkan range nilai aktivitas air terhadap pemanasan dan lamanya pengeringan yang berbeda-beda yaitu 0,2 - 0,1 pada suhu $70^{\circ} \mathrm{C}, 0,2-0,09$ pada suhu $80^{\circ} \mathrm{C}$, dan $0,2-0,04$ pada suhu $100^{\circ} \mathrm{C}$.
Berdasarkan data penelitian diatas (gambar 4) semakin tinggi suhu dan lama waktu pemanasan akan semakin kecil pula nilai aktivitas airnya. Pengeringan pada suhu $100^{\circ} \mathrm{C}$ memeperoleh data range nilai aktivitas air lebih kecil yaitu 0,2 - 0,04 dibandingkan dengan pengeringan dengan suhu $70^{\circ} \mathrm{C}$. Perbedaan yang terjadi tidak begitu menclok dikarenakan perbedaan suhu pemanasan yang tidak terlalu tinggi. Dalam penelitian tentang modifikasi dan pengujian alat pengasap ikan sistem cabinet oleh Bimantara (2015), menyebutkan bahwa aktivitas air yang rendah disebabkan oleh suhu pemanasan dan daya hantar listri yang tinggi.

\section{KESIMPULAN}

Praktikum pengeringan simplisia kunyit jenis kunyit orange dan putih dengan variabel suhu dan ketebalan irisan didapatkan hasil optimum yaitu pada suhu $80^{\circ} \mathrm{C}$ untuk kunyit 
orange, yaitu kadar air sebesar 32,386 \% dengan lama pengeringan 135 menit dengan bau khas kunyit, warna orange terang, dan bentuk fisik yang keriput serta nilai aktivitas air berkisar antara $0,2-0,04$. Sampel kunyit putih variabel optimum pada suhu $80^{\circ} \mathrm{C}$, kadar air sebesar $19,46 \%$ dengan penampakan fisik warna putih kekuningan dan bau sedikit khas kunyit, serta nilai aktivitas air antara 0,2-0,09.

Grafik hubungan lama waktu pengeringan terhadap kadar air dan aktivitas air didapat hubungan grafik yang linier yang mana semakin tinggi suhu semakin banyak air dalam bahan yang teruapkan sehingga kadar air dalam bahan semakin menurun, begitupula dengan nilai aktivitas air semakin tinggi dan lama waktu pengeringan semakin kecil nilai aktivitas air dalam bahan.

\section{DAFTAR PUSTAKA}

Belitz, H.D., Grosch, W. \& Schieberle, P., 2009. Springer Food chemistry 4th revised and extended edition. Annual Review Biochemistry, 79:655-681.

Bimantara F. 2015. Modifikasi dan Pengujian Alat Pengasapan Ikan Sistem Kabinet. Inderalaya: Fakultas Pertanian, Universitas Sriwijaya. [Skripsi].

Ferreira, F.D., Kemmelmeier, C., Arrotéia, C.C., da Costa, C.L., Mallmann, C.A., Janeiro, V., Ferreira, F.M.D., Mossini, S.A.G., Silva, E.L. \& Machinski, M., 2013. Inhibitory effect of the essential oil of Curcuma longa L. and curcumin on aflatoxin production by Aspergillus flavus Link. Food Chemistry, 136(2):789-793. doi: 10.1016/j.foodchem.201 2.08 .003
Fitriyono, A. 2014. Teknologi Pangan : Teknologi Praktis dan Aplikasi. Yogyakarta : Graha IImu

Kössler, S., Nofziger, C., Jakab, M., Dossena, S. \& Paulmichl, M., 2012. Curcumin affects cell survival and cell volume regulation in human renal and intestinal cells. Toxicology, 292(2), pp.123-135.

Kusumaningrum, H.P., Kusdiyantini, E. \& Pujiyanto, S., 2015. Kualitas Simplisia Tanaman Biofarmaka Curcuma domestica Setelah Proses Pemanasan Pada Suhu Dan Waktu Bervariasi. Bioma, 17(1), pp.27-33.

McCabe, W.L., Smith, J.C. \& Harriott, P., 1993. Unit operations of chemical engineering (Vol. 5, p. 154). New York: McGraw-Hill.

Rahmawan, 2001. Pengeringan, Pendinginan, dan Pengemasan Komoditas Pertanian. Direktorat Pendidikan Kejuaraan. Jakarta.

Rukmana, R. 1994. Temulawak : Tanaman Rempah dan Obat. Kanisius : Yogyakarta

Saputra, A \& Dewi, K.N. 2010. Pengeringan Kunyit dengan Menggunakan Microwave dan Oven. Jurusan Teknik Kimia, Fakultas Teknik : UNDIP

Septiana, A.T., Mustaufik, H.D., Muchtadi, D., Zakaria, F. \& Ola, M.M., 2006. Pengaruh spesies zingiberaceae (Jahe, Temulawak, Kunyit, dan Kunyit Putih) dan ketebalan irisan sebelum pengeringan terhadap kadar dan aktivitas antioksidan ekstrak aseton yang dihasilkan= Effect of Zingiberaceae. Agritech, 26(2006).

Trujillo, J., Chirino, Y. I., Molina-Jijón, E., AndéricaRomero, A. C., Tapia, E. T., \& PedrazaChaverrí, J.2013. Renoprotective effect of the antioxidant curcumin: Recent findings. Mini Review. Redox Biology, 448-456.

Winarto, WP. 2004. Khasiat dan Manfaat Kunyit. Agromedia Pustaka : Jakarta 